\title{
EL CONCEPTO \\ DE HOMBRE Y \\ LA TIERRA \\ (2007)
}

Kant, el gran filósofo de Königsberg, en un curso que solía impartir en los veranos sobre la filosofía en sentido pragmático, decía: "La filosofía se reduce a estas cuatro preguntas: ¿Qué puedo conocer, qué debo hacer, qué puedo esperar y qué es el hombre?" Y agregaba: "respondiendo la última, se pueden contestar las demás".

La segunda de estas importantísimas preguntas “¿qué debo hacer?” (que corresponde a la ética), solo puede contestarse si tenemos una idea clara y correcta de lo que el hombre es. Esto está fuertemente relacionado con la ecología: ¿Qué es el hombre en la tierra? ¿Cuál es su relación con la tierra? ¿Qué debe hacer por la tierra?

Es evidente que las contestaciones a estas interrogantes son muy diferentes dependiendo del concepto de hombre que se tenga. Un ejemplo excelente es la carta del indio Seattle al gobernador de Washington, que le proponía comprar las tierras de su tribu. Noah Seattle escribe al hombre blanco: “¿Cómo se podrá comprar o vender el firmamento, ni aún el calor de la tierra? No somos dueños de la frescura del aire, ni del fulgor de las aguas, ¿cómo podrán ustedes comprarlos? Cada parcela es sagrada para mi pueblo [...] La tierra no pertenece al hombre, el hombre pertenece a la tierra".

De esta concepción del hombre y de la tierra se sigue un enorme respeto y amor al planeta. Tal vez el caso más opuesto es el del Homo oeconomicus que creció y se fortaleció en la Revolución Industrial 
cuando, según Lewis Mumford: "los valores de la vida fueron sustituidos por los valores económicos". Este hombre insaciable, en expresión de Jacques Ellul, tiene entrañas de metal, aprecia más al dinero que a las personas y usa a las personas como mercancías y como medios de producción de más ganancia y dinero.

Este Homo oeconomicus, obeso y obsceno, es el gran depredador, el gigante agresor de la naturaleza: destroza los bosques, lo que equivale a perforar el pulmón de la tierra, solo para convertir la madera en dinero; mata cruelmente a millones de animales, muchas veces solo para comercializar las pieles o para divertirse; explota irracionalmente los recursos no renovables, porque son una inmensa fuente de ganancia sin importar la destrucción del medio, el efecto invernadero, el rompimiento del maravillosísimo equilibrio entre plantas, animales y humanos. Y lo que es aun peor, este Homo oeconomicus es el enemigo más cruel de todos los millones de hombres que trata como mercancía barata, que los explota como esclavos de la necesidad con trabajos inhumanos y salarios miserables; que los mueve como marionetas con los hilos invisibles de una dominación permanente y destructora.

El Homo oeconomicus es la encarnación deforme de la afirmación de Protágoras sobre que "el hombre es la medida de todas las cosas".

222 Es la explosión del liberalismo sin freno, que en expresión del John Stuart Mill, "en lo que solo a sí concierne, el hombre es soberano sobre sí mismo, su cuerpo y su espíritu” y que quiere extender su soberanía a todo el universo. Es el hombre renacentista que, según Soljenitsin, se siente y actúa como dueño y señor del universo.

Es urgente y necesario reconocer que este espécimen humano degradado y peligroso es la causa de los principales males que vivimos: de las guerras que compran petróleo y dominación con vidas humanas; de las terribles injusticias sociales que permiten disfrutar al $20 \%$ privilegiado del mundo del $86 \%$ del producto total, mientras el $20 \%$ de desheredados solo posee el $1 \%$ de la riqueza del mundo; del cretinismo del poder que coloca 900000 millones de dólares para armas junto a cuarenta millones de personas que mueren de hambre; y hasta de la educación, que convierte tantas escuelas en industrias productoras del material humano que demandan los bancos y el mercado. 
Es igualmente necesario y urgente poner un alto a la devastación producida por el Homo oeconomicus, obeso y obsceno, si queremos una sociedad más libre, más justa y más humana. Y la única manera de hacerlo es fortaleciendo al Homo sapiens, al "hombre humano que empieza por definir su esencia como el invitado de honor al misterio de la vida", el hijo de Dios, el encargado de custodiar a todos los hombres a la casa del hombre, a los satisfactores de las necesidades de todos los hombres.

El Homo sapiens acepta sus limitaciones y sus dependencias. Está muy lejos de sentirse soberano porque, como dicen lo más grandes filósofos griegos y los más grandes filósofos de todos los tiempos, existe el arjé, el principio, el Señor del Universo.

Bien decía Leszek Kolakowsky: "La utopía de la perfecta autonomía del hombre y la esperanza de la ilimitada perfección pueden ser los instrumentos más eficientes del suicidio que jamás haya inventado la cultura humana. Rechazar lo sagrado es también rechazar nuestros propios límites. Es también rechazar la idea del mal [...] La cultura, cuando pierde su sentido sagrado, pierde todo su sentido".

Por su parte, Jacques Attali, en El milenio, cuando se refiere al necesario abandono de la supuesta soberanía y a la necesidad de aceptar nuestros límites, afirma: "Este nuevo milenio será magnífico o terrible dependiendo de nuestra habilidad para limitar nuestros sueños. No todo es ni debe ser posible. Debemos adquirir la sabiduría para abreviar nuestra fantasía: traspasamos ciertos límites (éticos o biológicos) por nuestra cuenta y riesgo con terribles consecuencias. Para poder crear una civilización que perdure, la humanidad debe reconciliarse con la naturaleza y con ella misma. Debe adoptar una cultura tolerante y pluralista que esté imbuida con un profundo sentido de lo sagrado".

Así piensa el Homo sapiens, el hombre humano, el que debe triunfar frente al Homo oeconomicus y todas sus infamias. 
CITAM Derechos Reservados.

La reproducción total o parcial de este artículo se podrá hacer si el ITAM otorga la autorización previamente por escrito. 